\title{
胆囊粘莫癌について
}

\begin{tabular}{lrlll}
\multicolumn{5}{c}{ 金沢大学医学部第2 外科 } \\
野口 & 昌邦 & 永川 & 宅和 \\
倉知 & 圓 & 宮崎 & 逸夫
\end{tabular}

\section{INTRAMUCOSAL CARCINOMA OF THE GALLBLADDER}

\section{Masakuni NOGUCHI, Takukazu NAGAKAWA, Koichi MIWA, Madoka KURACHI and Itsuo MIYAZAKI}

The Second Department of Surgery, Kanazawa University School of Medicine

察引用語：胆囊粘膜癌，早期胆衰癌

\section{Iはじめに}

近年, 消化器系癌の治療成績は, 漸次向上されつつあ るがこれは積極的な搪大根治手術と共に，早期発見， 早期手術に負らところが大きい. 胆道系癌においても， 近年, PTC, ERCP，血管造影法などの開発，進歩によっ て，その診断はかなり容易になってきたが，早期診断は 難しく，外科的治療成績も不良である。なかでも，胆衰 癌はその解剖学的特性から早期診断はさらに困難である といわれ，諸家の報告例をみても，その長期生存例は術 中または術後, 偶然に発見された胆衰粘膜癌が大部分を 占めている.

教室 では過去18年間に, 胆雍癌手術症例77例を経験 し，その成績などについてはたびたび報告してきた

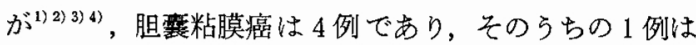
術前に疑診されているので，本稿ではこの 4 症例を供覧 し，胆蓓癌の早期発見の可能性とその治療について，文 献的考察を加觉，私見を述べたい.

\section{II症例}

患者 1.51歳の女性で, 右悸肋部疼痛を主訴とした。 経静脈性胆道造影法を施行するも胆裹の造影をえず，総 胆管の払張を認めた。胆石症の診断にて手術を施行し，

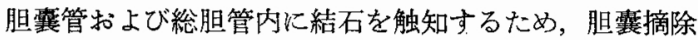
扣よび総胆管切開術を施行した。総胆管内より 2 個のコ 系石を摘出し，摘除胆囊内に 1 個のコ系石を認めた。摘 除胆襄の胆霊管粘膜に結石の圧迫による潰瘍を認めた が，胆衰粘膜には肉眼的に異常所見は認めなかった（図 1). しかし, 病理組織学的に偶然, 胆霊体部の一部粘
因 1 症例 1 . 摘除胆整.

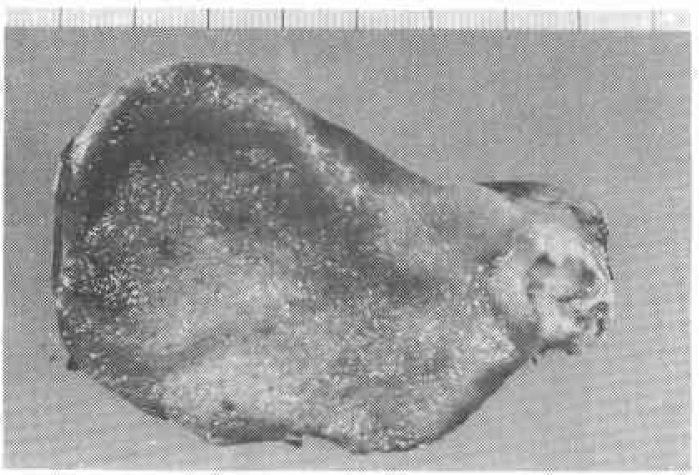

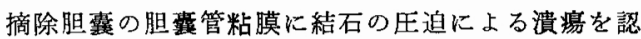
めたが，胆囊粘膜に隆起，陥凹，肥厚などの所見は 認めなかった。

膜に招いて，上皮は多層性，屈曲，分岐の傾向を示し （図 2 ）, 上皮細胞は大型濃染核を有し，異型性を認め， 粘膜の Intraductal adenocarcinoma と診断された。リ ンパ節転移は認めず，現在，術後約15年を経過するが健 在である.

患者 2.71歳の女性で, 右悸肋部疼痛と発熱を主訴と した、某医を受診し，急性化膿性胆囊炎と診断された が，全身状態不良のため胆辢外㿉造設術のみ施行され， 当科に紹介された，当科入院時，胆囊外瘻はすでに閉鎖 していたため，点滴法胆道造影法を施行したところ，胆 輩内に中心部に石灰化像を有する卵円形の透亮像を認め た（図 3 )。との他に胆裹体部肝葴側に輸厗不鮮明な陰 
図 2 症例 1 (H\& E 染色, $\times 40)$

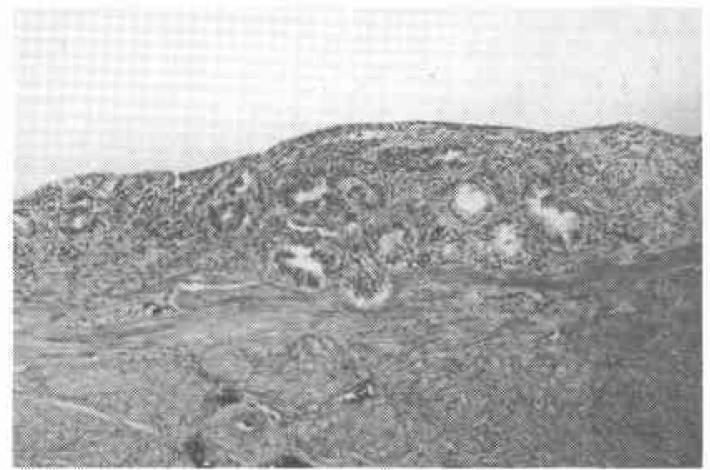

粘膜上皮は多層性，座曲，分岐の傾向を示し，上 皮細胞は大型濃染核をむち，異型性を認め，Intraductal carcinoma 子診断された。

\section{図 3 症例 2. 点滴法胆道造影}

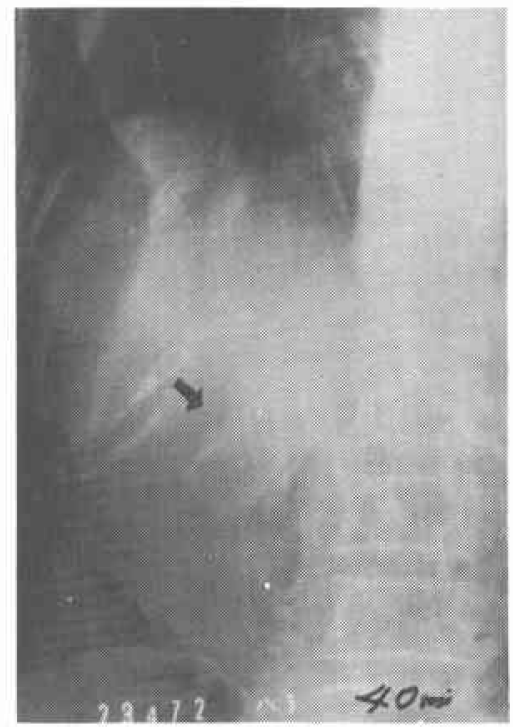

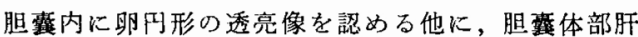
臓側に輪廍不鮮明な陰影欠損像 (矢印) を認めた。

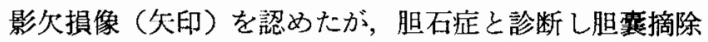
術を施行した。摘除胆襄内にビ系石 1 個を認めると共 に，胆慗体部粘膜に花野菜状の腫瘍を認めたので（図

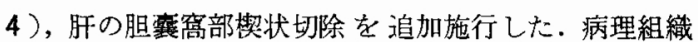
学的に腫瘍は広い茥を持ち, 密な樹枝状に分岐した間質 に支持された円柱上皮の不規則な乳頭状増殖であり（図 5 ), 細胞は大型化, 多層性の傾向を示し, polarity を 失い，核は大型濃染化し異型性を認め, 分化型乳頭状腺 癌と診断された。癌細胞は粘膜内にとどまって扣り, リ
目 4 症例 2 . 摘除胆栾と結石

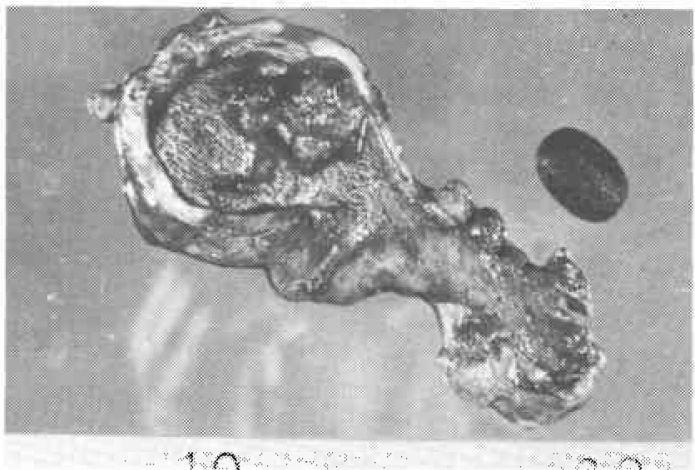

摘除胆囊内にビ系石 1 個とと\&に，花野菜状の腫演 を認めた。

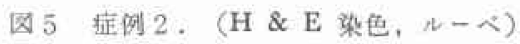

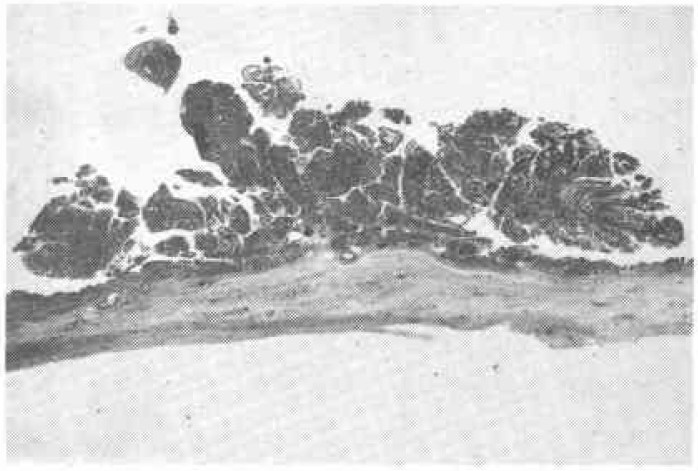

厸い茎をるつ乳頭状の腫湯であり，分化型乳頭状腺 癌之診断された。

ンパ節転移は認めなかった．現在，術後約 8 年を経過す るが健在である。

患者 3.57歳の男性で，右悸肋部疼痛を主訴とした。内 視鏡的逆行性胆道造影 (ERCP) を施行したところ，胆 襄は体部中程にくびれを有し，体部から底部にかけて腹 腔側に不規則な陰影欠損像を認め，体位変換によっても その陰影欠損像の位置は変らなかった（図6). 胆霊癌 の疑診にて胆囊摘除術を施行した。摘除胆衰は肉眼的に 慢性肥厚性胆襄炎の所見を呈していたが（図7），病理 組織学的に胆䒼体部，くびれより頝部側の粘膜におい て，上皮は多層性の傾向を示し，上皮細胞は大型濃染核 を有し Polarity を失い異型性を認めたが，基底膜が保 たれていることから Carcinoma in situ と診断された (図8).リンパ節転移は認めなかったが，術後 5 年 2 力 月にて原発性肝癌のため死亡した. 
図 6 症例 3.内視鎮鏡的逆行性胆道造影.

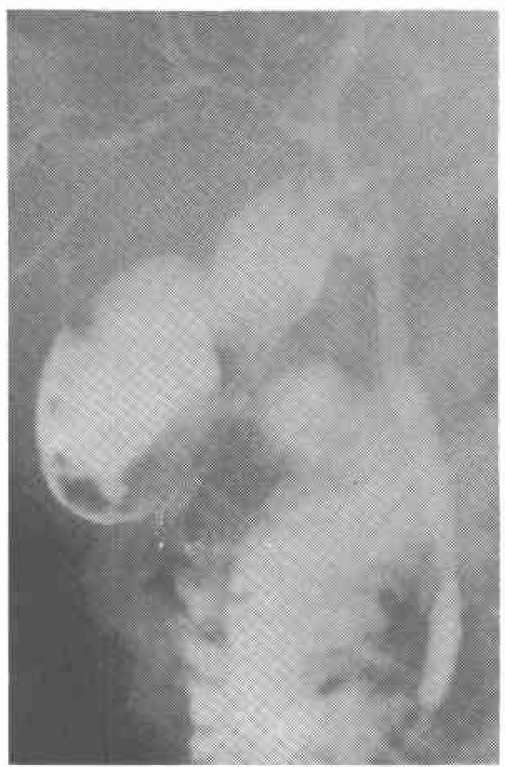

胆襄体部から底部にかけて腹腔側に不規則な陰 影欠損像を認めた。

図 7 症例 3 . 摘除胆囊

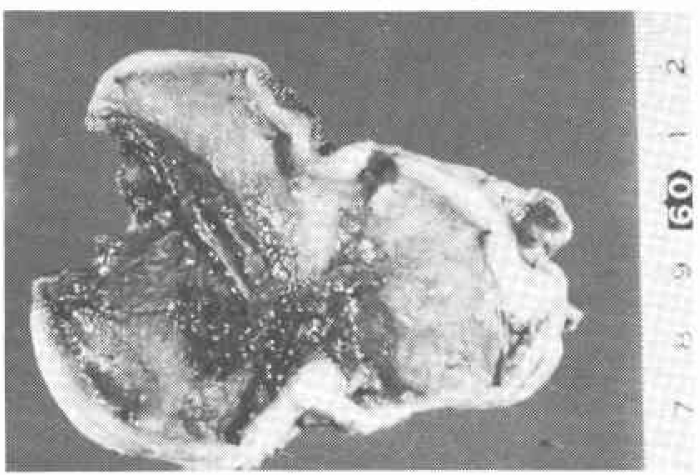

肉眼的には慢性肥厚性胆囊炎の所見を呈していた。 底部の一部は術中凍結診断のため切除されている。

患者 4.68歳の男性で, 右悸肋部疼痛を主訴とした。 経口的胆䧶造影および静脈性胆道造影法を施行したが, 胆囊および総胆管の造影はえられなかった。胆石症の診 断にて手術を施行し, 胆囊および総胆管内に多数の結石 を触知するため, 胆献摘除および総胆管切開術を施行し た. 総胆管内より 8 個のコ系石を摘出し, 摘除胆囊内に 119 個のコ系と粘膜に米粒大から $3.2 \times 2.0 \mathrm{~cm}$., までの多 発性腫瘍を認めた（図9）. 病理組織学的には比較的分 化した乳頭腺管癌であり, 癌細胞は粘膜下層にまで及ぶ
図 8 症例 3.（H \& E 染色, × 200)

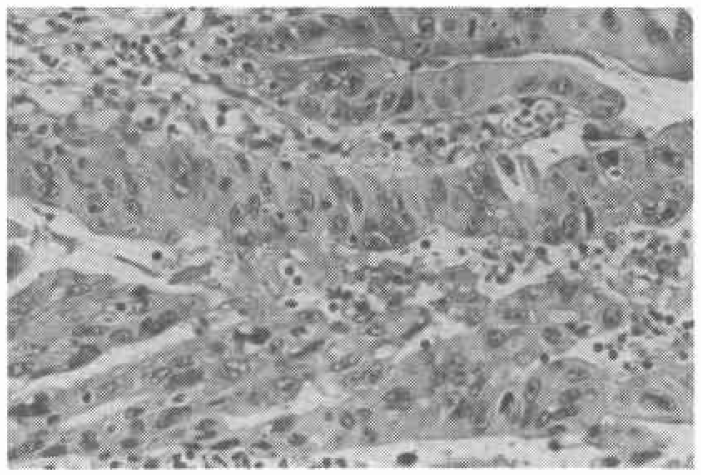

粘膜上皮は多層性の傾向を示し, 上皮細胞は大型濃 染核をもち，polarityを失い異型性を認め，carcinoma in situ と診断された。

図 9 症例 4 . 摘除胆壤と結石

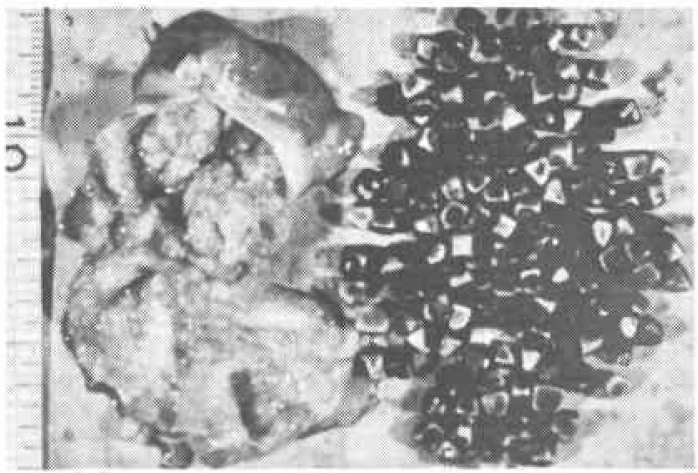

摘除胆軎内に 119個のコ系石とともに，米粒大から $3.2 \times 2.0 \mathrm{~cm}$ までの多発性腫湯を認めた。

図10 症例 4 (H \& E 染色, ルーペ)

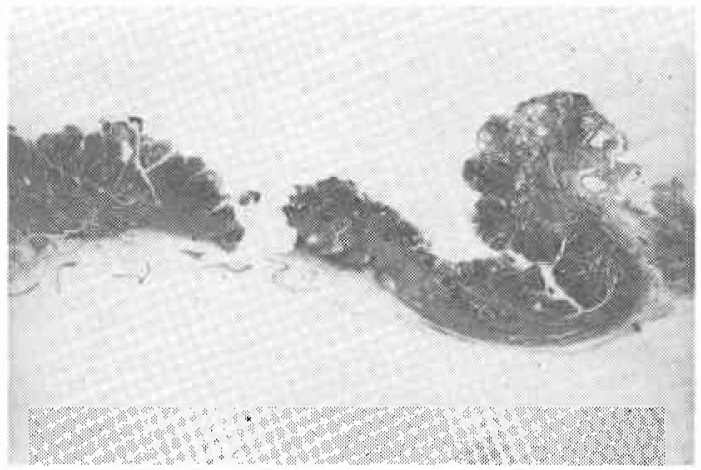

比較的分化した乳頭状腺癌で, 粘膜下層にまで及ぶ が筀層への浸潤は認めなかった。 
が筋層への浸潤は認めず（図10), リンパ節転移は認め なかった。現在, 術後約10年を経過するが健在である.

\section{III 考 察}

早期胆襄癌の定義については，先般，出された日本胆 道外科研究会発表の胆豊癌の外科取扱い規約 (案) ${ }^{5)}$ で も明らかにされていない。これは各施設とも，早期の胆 襄癌症例が少なく，その実体を把握しがたいなどのため と考元られる.1974年，棉原ら ${ }^{6)}$ は胆襄には他の消化管 飞存在する粘莫筋板が欠如しているといら特徵があり， 胆黹の筋層は胃の固有筋層に相当するものとの考兄か ら，癌浸潤が胆裹粘莫あるい性粘膜下層にとどまり。 筋層におよばないものを早期胆衰癌とするのが妥当であ ると述べている。また，Nevin らつは胆軎癌の進行度を その深達度から5つの stage に分類しているが，その らちの stage Iが胆集粘莫癌に一致している。これら の観点からすると，今回，私共が供覧した胆襄粘膜癌 は，いわゆる早期胆哓癌と称されるべきものと考えられ る。

胆趼癌の診断认は，従来の検查法の中では経皮経肝胆 管造影 (PTC), 内視鏡的逆行性胆道造影 (ERCP), 選 択的動脈造影拉よび腹腔鏡検査などが有用であるといわ れている。しかし，私どもの経験からすると，選択的腹 腔動脈造影㧍よび腹腔鏡検查は進行した胆囊癌の診断に は有力であるが，早期猃断的価値は少なく，これに対し て PTC および ERCP などのいわゆる直接胆道造影法 は，胆垔粘膜面の変化をとらえらることから，胆雃癌に 特ける早期診断的価值は前者济較べて高い上らである. すなわち, 症例 3 では ERCP にて術前に胆衰癌の疑診 を只て扮り，また，症例 2 では点滴法胆道造影法にて胆 襄内に不鮮明な陰影欠損像を認めていることから，さら に直接胆道造影法が施行されたならば，その診断は可能 であったと考えるからである。しかし，胆䉴管に結石の 嵌頓を合併する症例 1 ．中胆襄内に結石が充満している 症例 4.の上らな場合には，PTC や ERCPを施行して も胆変の造影をえることはできない，そこで，私どもの 教室では PTC や ERCP によっても胆裂の造影がえら れない症例に対しては，経皮経肝的に直接胆踖を穿刺造 影する選択的経皮経肝胆豪造影法 (S-PTC) と穿刺細胞 診(4)を，すでに60例近くの症例に行ってきたが，まだ 胆慗粘膜癌の症例に遭遇していないものの，切除可能な

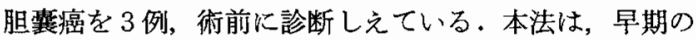
胆襄癌の発見に有用であるるのと期待している.

さて，䏣霟粘膜癌の治療については，私どもの症例
では肝の楔状切除を追加施行した 1 例を除いて, 他の 3 例はすべて単純胆襄摘除のみ一行われている，諾家の報 告例をみても，前述したように胆变粘膜癌は切除後に判 明したものが多く，その予後も単純胆摘の及で良好であ るようであるが，胆震の粘膜下層にはリンバ路が密に連 絡交通していることから，Carcinoma in situ と確診で きない限り，早期の胆毫癌こそ，Glenn") の提唱する肝 の胆䯧窝部を楔状に切除して胆哓を摘除し，肝十二指腸 靬帯より十二指腸にいたる奬膜を切除し，総胆管周囲り ンパ節を廓清する手術を行うべきであると考える。 た，周知のごとく，胆震癌は結石を合併することが多 く, 胆衰結石症の単純胆摘術に際しては, 必らず術中に 胆裏を切開し，もし粘膜面の異常が認められたならば， 積極的に術中凍結組織診断を行い，癌の有無を確認する ことが，診断はもちろん治療上も重要であることを強調 した(、1)310).

\section{IV まとめ}

胆慜粘莫癌の 4 症例を供覧すると共にその診断と治 療について若干の考察を行った。すなわち, 胆鸾粘膜癌 の術前診断は現時点では, 胆震粘膜面の变化をとらえう るPTC，ERCP および S-PTCが有用であり，その手術 術式としては Glenn の提晿する肝の楔状切除とリンパ 節廍清を行う拡大胆摘が 望ましいるのと考文る。ささら

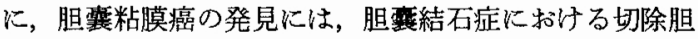
裹の粘膜面の術中観察が重要であることを強調した。

\section{文献}

1）野口昌邦他：早期胆榷癌 の 1 例. 外科, 37 : 515-518, 1975.

2) 野口昌邦他 : 胆のう癌の長期生存例について。 外科診療, $18: 1275-1278,1976$.

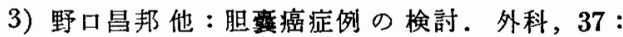
$847-850,1975$

4) 永川宅和他：胆癌の診断々治療。日消外会 誌, 9 ：157-162, 1976.

5）日本胆道外科研究会：胆算癌の外科取扱い規約 案, 1978 .

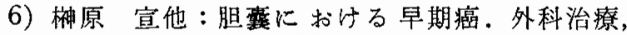
$30: 137-140,1974$.

7) Nevin, J.E., et al.: Carcinoma of the gallbladder. Cancer, 37: 141-148, 1976.

8）永川宅和他：胆落癌へのアプローチ, 選択的経 皮経肝胆螆穿刺造影法。医学のあ㠴之，94： $150-151,1975$.

9) Glenn, F., et al.: The scope of radical surgery in the treatment of malignant tumor of the extrahepatic biliary tract, S.G.O., 99: 529$541,1954$.

10）宮崎逸夫 他：組織検查で判明した胆囊癌。外 科, 40：636-640, 1978 . 